\title{
Molecular Authentication of Meats from Three Terrestrial Birds Based on Pcr-Rflp Analysis of the Mitochondrial 12S rRNA Gene
}

\section{-Author(s)}

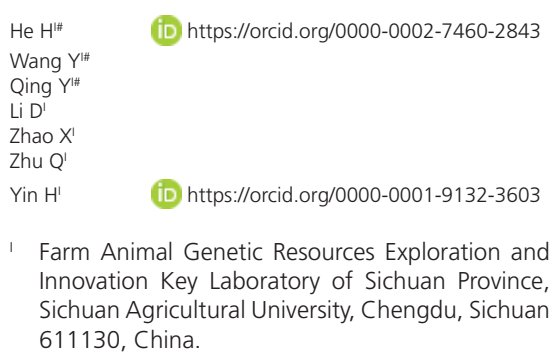

\#These authors contributed equally to this work.

\begin{abstract}
In this study, a method utilizing PCR-restriction fragment length polymorphism (PCR-RFLP) of a mitochondrial gene was developed for the identification of chicken (Gallus gallus), quail (Coturnix coturnix), and common pigeon (Columba livia) meat. PCR products of $\sim 440 \mathrm{bp}$ were obtained from the $12 \mathrm{~S}$ rRNA gene of these three birds using a pair of universal primers. The three terrestrial birds can be distinguished using one restriction endonuclease, Alu I, which was selected based on species-specific variations in the mt $12 \mathrm{~S}$ rRNA gene sequence using 9 newly-obtained and 44 published chicken, quail and pigeon sequences. This method was also successfully used to identify commercial quail and pigeon meat products, which were found to be adulterated with chicken meat. Additionally, our method had relatively high sensitivity for detecting a meat mixture. Ten percent of chicken meat in the mixed quail and pigeon sample was detectable. This assay can be useful for the accurate identification of meats from terrestrial birds, avoiding mislabeling or fraudulent species substitution in meat products.
\end{abstract}

\section{INTODUCTION}

In 2015, the total stock of specialized commercial layer breeders was about 1.25 billion in China, which means that the same number of male chicks needs to be properly disposed at day-of-hatch. Commonly, most of males are used as a source of protein for animal feed, and a few are raised to produce human food. It was recently reported that the specially processed male chicks were used to manufacture counterfeit quail and pigeon meat products. The meat of quails and pigeons have high levels of polyunsaturated fatty acids and low intramuscular fat content, which are desirable to consumers(Maiorano et al., 2011), but their production costs are several times higher than that of culled male chicks in China. Moreover, it is very difficult to detect adulterations in chicken, quail and pigeon products with the unaided eye due to their similarity in appearance, particularly if the food changes drastically after specialized processing, such as frying, baking, pickling or removing the head, feet and wings, etc., thus hampering the visual identification of the product (Drummond et al., 2013). Moreover, packaging labels do not provide sufficient guarantees, and therefore, it is imperative to develop an accurate and rapid method for the identification of quail and pigeon meat products, not only because of commercial protection and unfair economic competition, but also for the sake of public health, such as allergies.

In recent years, a variety of techniques have been suggested for the identification the species origin of meat products, including chromatography (Leduc et al., 2012), spectroscopy (Rohman et al., 2011), and protein (Hsieh et al., 2015), and DNA assays (Safdar \& Junejo 
2015). The methods based on physicochemical and protein analyses have high sensitivity and throughput to detect raw meats, but have limited application in cured, fermented, chemically-treated or highlyprocessed meats, because proteins can be denatured by high temperature, pressure and other processing methods (Soares et al., 2013). In contrast, DNA is a relatively stable molecule that can withstand the different heat and pressure treatments, and therefore, DNA-based techniques are more practical, sensitive and robust (Mafra et al., 2008).

Among the DNA-based approaches, polymerase chain reaction (PCR) coupled with techniques, including random amplified polymorphic DNA (RAPD) (Keeratipibul \& Techaruwichit 2012), restriction fragment length polymorphism (RFLP)(Céspedes et al., 2000), species-specific primer amplification (Amaral et al., 2015) nucleotide sequencing (Girish et al., 2004), or real-time PCR assays based on the use of fluorescent dyes and probes (Rojas et al., 2012), have been extensively utilized for the detection of animal species in a wide range of raw and processed meats. In PCR-RFLP, a conserved region of DNA sequence is amplified, followed by digestion with restriction enzymes, revealing the genetic variation among species (Partis et al., 2000). Several mitochondrial genes have been chosen as targets for the PCR-RFLP method due to their inherent multicopy presence and great sequence diversity(Wang et al., 2010). Among them, the mitochondrial 12S rRNA gene is one of the most widely used targets for animal product identification, such as beef, mutton, pork, venison, chicken, fishmeat etc.

In the present study, we tried to establish a reliable, rapid and economic assay for authenticating chicken (Gallus gallus), quail (Coturnix coturnix), and common pigeon (Columbalivia) meat products using a RFLP profile of the mitochondrial 12S rRNA gene. The appropriate restriction enzyme was selected according to the intra-species variation that was defined by the data gathered both from the sequences of this study and GenBank.

\section{MATERIALS AND METHODS}

\section{Sample collection and DNA extraction}

Live quails $(n=3)$ and live pigeons $(n=3)$ were purchased from commercial markets. The live chickens $(n=3)$ were obtained from the Poultry Research Farm of Sichuan Agricultural University. A total of nine pectoralis major muscle samples were collected from the birds, slaughtered according to animal welfare requirements of the Sichuan Agricultural University. The labeled quail $(n=7)$ and pigeon $(n=7)$ meat products were purchased from three different markets, and which are marked as processed meat.

Genomic DNA from raw meat was using the standard phenol/chloroform method. Genomic DNA from processed meat was extracted by combining the guanidine hydrochloride lysis and phenol/chloroform methods, previously described by Chen et al. (2010). The purity and concentration of the extracted DNA samples were assessed based on 2\% agarose gel electrophoresis and NanoDrop Spectrophotometer at 260:280 nm (Bio-Rad, Wilmington, USA).

\section{PCR amplification and sequencing}

A pair of universal primers (Forward: 5'-CAA ACT GGG ATT AGA TAC CCC ACT AT-3'; Reverse: 5'GAG GGT GAC GGG CGG TGT GT-3') were used to amplify a fragment in the mitochondrial 125 rRNA gene (Kocher et al., 1989). The PCR was performed in a thermal cycler under the following conditions: 95 ${ }^{\circ} \mathrm{C}$ for $10 \mathrm{~min}, 35$ cycles of $94^{\circ} \mathrm{C}$ for $50 \mathrm{~s}, 62^{\circ} \mathrm{C}$ for $50 \mathrm{~s}, 72{ }^{\circ} \mathrm{C}$ for $60 \mathrm{~s}$, and a final extension at $72{ }^{\circ} \mathrm{C}$ for $10 \mathrm{~min}$. The $50-\mu \mathrm{L}$ reaction mixture contained 4 $\mu \mathrm{L}(50 \mathrm{ng} / \mu \mathrm{L})$ of DNA template, $25 \mu \mathrm{L}$ of $2 \times$ Taq PCR MasterMix (TIANGEN BIOTECH, Beijing, China), 17 $\mu \mathrm{L}$ of $\mathrm{ddH}_{2} \mathrm{O}$ and $2 \mu \mathrm{L}$ of each primer (10 pmol/ $\mu \mathrm{L}$ ). The PCR products were purified by a DNA Purification Kit (TIANGEN BIOTECH, Bejing, China) according to the manufacturer's instructions, and sequenced by Shanghai Yingjun Biology Technique Corporation.

\section{Restriction fragment length polymorphism}

The nine newly generated sequences from the PCR products were edited by DNAstar software (DNAS Inc, Madison, WI, USA) and were aligned with 44 reported mitochondrial 12S rRNA gene sequences of chicken ( $n$ $=29)$, quail $(n=8)$ and pigeon $(n=7)$ from GenBank (Supplemental Table 1). We identified species-specific variations by aligning the new sequences and database sequences for each species using the MEGA 6.0 software (Tamura et al., 2013).

The PCR products of 125 rRNA gene were digested with Alu I (Thermo, Beijing, China) at $37^{\circ} \mathrm{C}$ for $12 \mathrm{~h}$. The $30-\mu \mathrm{L}$ reaction components contained $10 \mu \mathrm{L}$ of PCR product, $2 \mu \mathrm{L}$ of restriction enzyme, $2 \mu \mathrm{L}$ of $10 x$ buffer, and $16 \mu \mathrm{L}$ of nuclease-free water. The digested products were visualized by electrophoresis on $12 \%$ polyacrylamide gel performed at $80 \mathrm{v}$ for $40 \mathrm{~min}$, and then $120 v$ for $30 \mathrm{~min}$ at room temperature. The gels were silver stained. 
Elsayed MAE, Mohamed NE, Hatab MH, Elaroussi MA

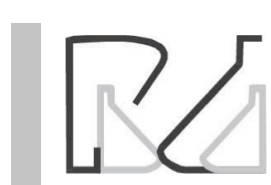

Table 1 - Mitochondrial 12S rRNA sequences of three terrestrial birds analyzed in this study.

\begin{tabular}{|c|c|c|c|}
\hline species & GenBank Accession No. & species & GenBank Accession No. \\
\hline \multirow[t]{15}{*}{ Chicken } & AJ490505 & Chicken & KF471517 \\
\hline & AJ583547 & & KF471518 \\
\hline & AJ849444 & & KF471520 \\
\hline & DQ885561 & & KF471521 \\
\hline & EU851896 & & KF471522 \\
\hline & EU851897 & & KF471523 \\
\hline & FJ610338 & & KF471524 \\
\hline & FJ610339 & & KF471525 \\
\hline & FJ610340 & & KF484729 \\
\hline & JN695757 & & KM224330 \\
\hline & JN695758 & & KM224331 \\
\hline & JN695759 & & KM224332 \\
\hline & JN695760 & & KM224333 \\
\hline & JN695761 & & KM224334 \\
\hline & KF471516 & & \\
\hline \multirow[t]{4}{*}{ Quail } & AM902516 & Quail & JN695769 \\
\hline & FN675551 & & JN695770 \\
\hline & JN695767 & & JN695771 \\
\hline & JN695768 & & KF469290 \\
\hline \multirow[t]{4}{*}{ Pigeon } & EF373295 & Pigeon & FN675580 \\
\hline & FN675577 & & FN675581 \\
\hline & FN675578 & & X87857 \\
\hline & FN675579 & & \\
\hline
\end{tabular}

\section{RESULTS}

\section{DNA Quantification}

In order to conduct PCR amplification of the mitochondrial 125 rRNA gene, the genomic DNA was extracted from the meat of the known birds and labeled quail and pigeon samples. There was obvious DNA degradation in processed quail and pigeon meat products. The DNA quantity measured by spectrophotometry showed the DNA concentrations were in the range of $320-2245 \mu \mathrm{g} / \mathrm{mL}$ with the A260:A280 ratios from 1.78 to 1.85 .

\section{PCR amplification and sequence analysis of the 12S rRNA gene}

PCR amplification was successfully performed using the universal primers on chicken, quail and pigeon samples. An amplicon about 440bp was visualized by electrophoresis. The identities of the amplicon were confirmed by direct sequencing of the PCR products. The lengths of the amplification
Molecular Authentication of Meats from Three Terrestrial Birds Based on Pcr-Rflp Analysis of the Mitochondrial 12S rRNA Gene

products of the mitochondrial $12 \mathrm{~S}$ rRNA gene of chicken, quail and pigeon were $445 \mathrm{bp}, 435 \mathrm{bp}$, and $446 \mathrm{bp}$, respectively. The newly-obtained sequences were deposited in GenBank, with the following accession numbers, for quail; KP211935, KP211936 and KP234018, for pigeon; KP211939, KP211940 and KP234021, and for chicken; KP211943, KP211944 and KP234022.

Together with the downloaded database sequences, the alignment of the 53 mitochondrial 125 rRNA gene sequences from the three terrestrialbirds revealed species-specific sequence variations. Consensus sequences of three species were constructed using the sequence of chicken $12 \mathrm{~S}$ rRNA as the reference sequence (figure 1). In total, we identified 65 single variable sites and 3 insertion/deletion sites in this dataset of mtDNA sequences, but no parsimony informative site was found.

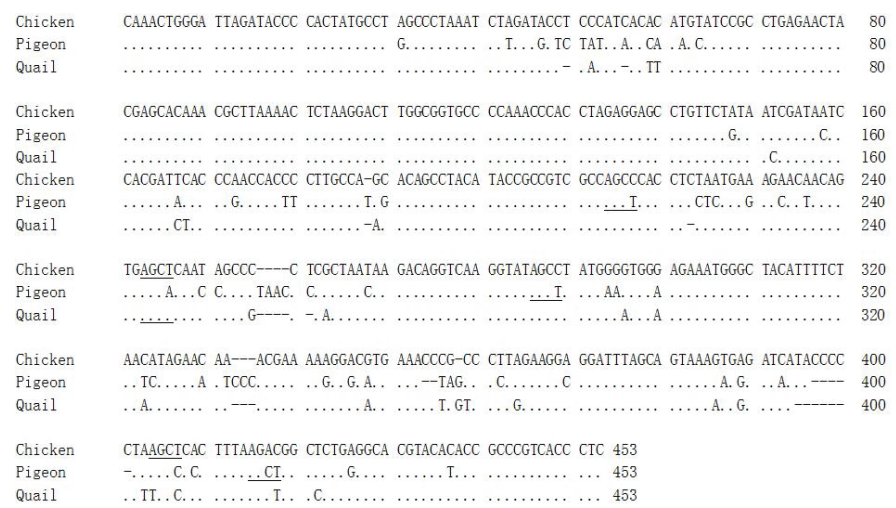

Figure 1 -Alignment of modified consensus sequences of the mitochondrial 12S rRNA gene fragment for three terrestrial birds.

The intra-species polymorphic sites identified in each species (chicken, $n=33$; quail, $n$ $=11$; and pigeon, $n=10$ ) are presented by IUPAC codes. The restriction sites of endonuclease Alu I ( $\left.5^{\prime}-A G \wedge C T-3^{\prime}\right)$ are underlined. Dots (.) denote the consensus with the references sequence (chicken). Short lines $\nabla-\nabla$ represent the base pair deletion relative to the reference sequence.

\section{Restriction fragment length polymorphism analysis}

\section{Meat samples of known bird species}

The PCR products obtained after amplification of $\mathrm{mt}$ $12 S$ rRNA gene were subjected to restriction enzyme digestion. According to the species-specific variations, one restriction enzyme, Alu I was chosen for restriction fragment length polymorphism analysis. As shown in the results in figure 2 , each bird species presented a unique specific RFLP pattern. Alu I digestion yielded three fragments (244 bp, 154bp and 47bp) for chicken, two fragments (241 bp and $194 \mathrm{bp}$ ) for quail, and four fragments (216 bp, 122 bp, 72 bp and 36bp) for pigeon, respectively. 
Elsayed MAE, Mohamed NE, Hatab MH, Elaroussi MA

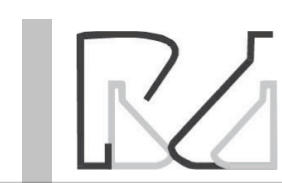

Molecular Authentication of Meats from Three Terrestrial Birds Based on Pcr-Rflp Analysis of the Mitochondrial 12S rRNA Gene

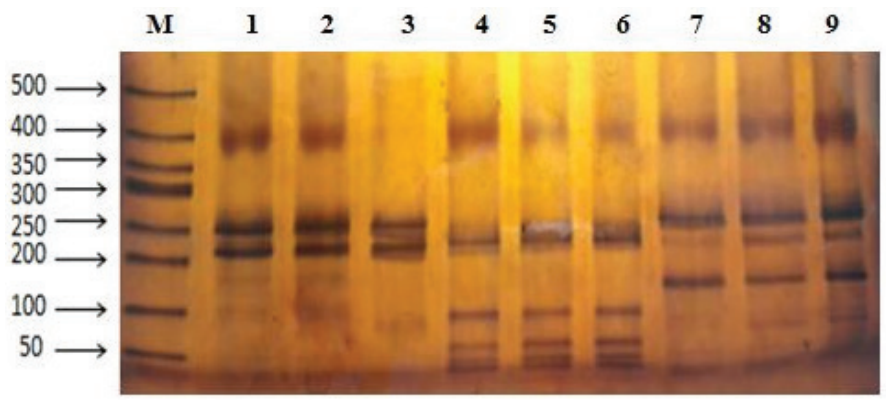

Figure 2 - Electropherogram of mitochondrial 12S rRNA gene fragments of three terrestrial birds digested by Alu I.

Lane M, 500 bp DNA ladder; lanes 1-3, chicken; lanes 4-6, pigeon; lanes 7-9, quail.

\section{Meat samples of tested birds}

In order to test the practical application of this methodology, we examined a total of 14 meat samples, including labeled quail and pigeon meat samples from different commercial markets. All samples were processed as described for the known bird species samples. Based on the results of the RFLP patterns by restriction Alu I (figure 3), three samples were identified as chicken in labeled quail meat and one sample was identified as chicken meat in labeled pigeon meat, which suggested that the labeled quail and pigeon meat was replaced by chicken meat at different levels. In order to validate the results of species identity obtained by the PCR-RFLP analysis, we sequenced the four amplicons that showed $100 \%$ homology to the partial sequence of chicken (Gallus gallus) mitochondrial $12 \mathrm{~S}$ rRNA gene.

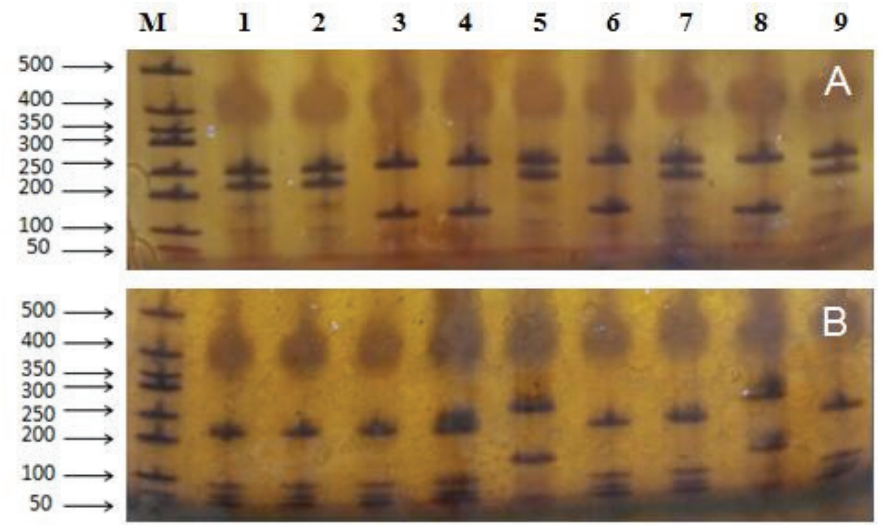

Figure 3 - Electropherogram of mitochondrial 12S rRNA gene fragments of so-called quail and so-called pigeon meats DNA digested by Alu I.

(A) Lane M, 500 bp DNA ladder; lanes 1-7, so-called quail; lane 8, definite quail; lane 9, definite chicken. (B) Lane M, 500 bp DNA ladder; lanes 1-7, so-called pigeon; lane 8, definite pigeon; lane 9, definite chicken.

\section{Sensitivity test}

In order to assess the sensitivity of the current method in detecting mixed meat products, deliberately adulterated mixed meat samples were prepared. Two meat mixtures (chicken and quail meat, and chicken and pigeon meat) at five ratios $(1: 9,2: 8,3: 7,4: 6$, and 5:5) were analyzed (figure 4). The electropherogram showed that it was possible to identify mixed quailchicken and pigeon-chicken meat products at all ratios tested.

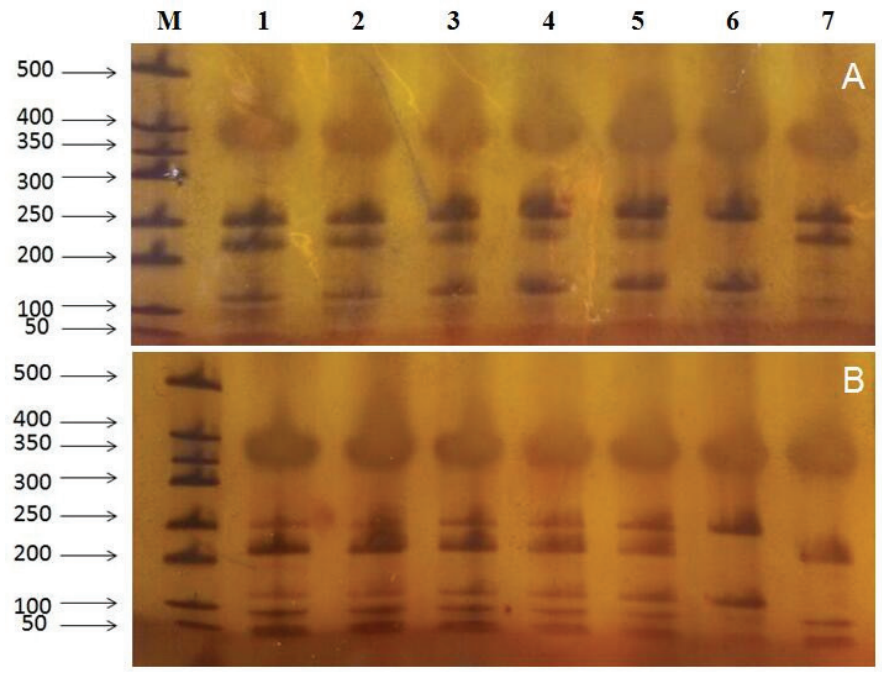

Figure 4 - Electropherograms of mitochondrial 12S rRNA gene fragments of mixed chicken and quail, and chicken and pigeon meats DNA digested with Alu I.

Lane $\mathrm{M}, 500$ bp DNA ladder; lane 1-5 refer to a mixture of chicken and quail (A), and chicken and pigeon $(B)$ in ratios of $1: 9,2: 8 ; 3: 7 ; 4: 6$, and $5: 5$; lanes $6-7$ are positive controls: pure chicken and quail (A), and pure chicken and pigeon (B), respectively.

\section{Discussion}

The identification of different species in meat foods and of different ingredients in processed food is often based on consumer requirements, administrative management, health concerns, economic demands, or religious choices (Aida et al., 2007). Although a number of molecular techniques have been applied to authenticate the origin of meat products, the DNAbased techniques developed in the recent past are found to be of potential value for the identification of meat animal species (Mahajan et al., 2011). Mitochondrial DNA sequence is highly conserved in different animal species, and thus the corresponding fragments can be amplified by universal primers for the $12 \mathrm{~S}$ rRNA gene in a wide variety of organisms (Kocher et al., 1989). Furthermore, general differences among mitochondrial 12S rRNA in different biological samples are sufficient to identify species by molecular techniques, such as PCR, RAPD, DNA hybridization, and gene sequencing (Partis et al., 2000). Each of these methods has their own advantages and limitations. PCR-RFLP was reported to be one of the most efficient approaches in terms of applicability, detectability, and economy and has been proven to be a practical, simple and rapid technique for large-scale identification(Chen et al. 2010). 
In the present study, the method of PCR-RFLP analysis targeting mitochondrial 125 rRNA gene was employed to identify terrestrial birds. This technique was effective in accurately identifying chicken, quail and pigeon meat samples. The expected PCR products were obtained for all samples, including in processed meat, suggesting that the universal primers used in our method are feasible. However, the PCR products obtained from processed meat were commonly short, because of the genomic DNA degradation. Using too many restriction endonucleases in one restriction digestion reaction is not advisable, even though more than one restriction endonuclease recognition sites are present in the targeted fragment. The results would be too short DNA fragments whose length polymorphisms cannot be clearly visualized (Zhang et al., 2006). In the present study, we only employed one endonuclease, Alu I, for RFLP analysis to identify three terrestrial birds. Authentication of quail and pigeon meat products bought from different markets also showed that this method is practical, and adulteration meat was identified.

The DNA-based methods are based on the assumption that species-specific genetic differences exist among the detected species (Hajibabaei et al., 2007). However, intra-species variations may cause a gain or loss of restriction sites which would obscure the inter-specific variation, especially when only a few samples are used to identify species-specific DNA sequence variations (Chen et al., 2012). However, our method can exclude the intra-species variations as much as possible by comparing the newly-generated sequences and downloading the published sequences. Of course, if more sequences for each species are collected, then more accurate and reliable results will be obtained.

Additionally, our method accurately detected the adulterated admixture of chicken and quail or chicken and pigeon at ratios from 1:9 to 5:5. This sensitivity is better than had been expected, because sensitivity problems were found using a similar method to detect mixed meat samples (Chen et al, 2010; Mahajan et al., 2011). For increased sensitivity, a real-time PCR assay may be a better choice. Compared with other molecular methods, such as terminal restriction fragment length polymorphism (Wang et al. 2010) and DNA sequencing (Mitani et al., 2009), and real-time PCR (Cammà et al., 2012), the PCR-RFLP procedure established in this study is more cost-effective and can be easily conducted in a laboratory without requiring specialized equipment.
In conclusion, the present study suggested an accurate and applicable analytical method to identify chicken, quail and pigeon meat based on the PCRRFLP analysis of $12 \mathrm{~S}$ rRNA of mitochondrial DNA. This method is useful and feasible to trace meat contamination. By analyzing a relatively large number of sequences in one species, it is possible to avoid the false identification caused by the interruption of intraspecies variation.

\section{ACKNOWLEDGMENTS}

We thank Dr. Eric A Wong (Virginia Tech, Blacksburg, VA, USA) for revising the English. This work was financially supported by the China Agriculture Research System (CARS-40), and the Thirteenth Five Year Plan for Breeding Program in Sichuan (2016NYZ0050).

\section{REFERENCES}

Aida AA, Man C, Yaakob B, Raha AR, Son R. Detection of pig derivatives in food products for halal authentication by polymerase chain reactionrestriction fragment length polymorphism. Journal of the Science Food and Agriculture 2007;87(4):569-572.

Amaral JS, Santos CG, Melo VS, Costa J, Oliveira MBP, Mafra I. Identification of duck, partridge, pheasant, quail, chicken and turkey meats by species-specific PCR assays to assess the authenticity of traditional game meat Alheira sausages. Food Control 2015;47:190-195.

Céspedes A, García T, Carrera E, González I, Fernández A, Asensio L, et al. Genetic differentiation between sole (Solea solea) and Greenland halibut (Reinhardtius hippoglossoides) by PCR-RFLP analysis of a $12 \mathrm{~S}$ rRNA gene fragment. Journal of the Science Food and Agriculture 2000;80(1):29-32.

Cammà C, Di Domenico M, Monaco F. Development and validation of fast real-time PCR assays for species identification in raw and cooked meat mixtures. Food Control 2012;23(2):400-404.

Chen S, Liu Y, Yao Y. Species authentication of commercial beef jerky based on PCR-RFLP analysis of the mitochondrial 12S rRNA gene. Journal Genetics and Genomics 2010;37(11):763-769.

Chen S, Yao Y, Liu Y. Species identification of ten common farm animals based on mitochondrial 12S rRNA gene polymorphisms. Animal Biotechnology 2012;23(3):213-220.

Drummond M, Brasil B, Dalsecco L, Brasil R, Teixeira L, Oliveira D. A versatile real-time $P C R$ method to quantify bovine contamination in buffalo products. Food Control 2013;29(1):131-137.

Girish P, Anjaneyulu A, Viswas K, Anand M, Rajkumar N, Shivakumar B, et al. Sequence analysis of mitochondrial $12 \mathrm{~S}$ rRNA gene can identify meat species. Meat Science 2004;66(3):551-556.

Hajibabaei M, Singer GA, Hebert PD, Hickey DA. DNA barcoding:how it complements taxonomy, molecular phylogenetics and population genetics. Trends in Genetics 2007;23(4):167-172.

Hsieh MK, Shih PY, Wei CF, Vickroy TW, Chou CC. Detection of undeclared animal by-products in commercial canine canned foods:Comparative analyses by ELISA and PCR-RFLP coupled with slab gel electrophoresis or capillary gel electrophoresis. Journal of the Science Food and Agriculture 2015;96(5):1659-1665. 
Keeratipibul S, Techaruwichit P. Tracking sources of Listeria contamination in a cooked chicken meat factory by PCR-RAPD-based DNA fingerprinting. Food Control 2012;27(1):64-72.

Kocher TD, Thomas WK, Meyer A, Edwards SV, Pääbo S, Villablanca FX, et al. Dynamics of mitochondrial DNA evolution in animals:amplification and sequencing with conserved primers. Proceedings of the National Academy of Sciences of the United States of America 1989;86(16):61966200.

Leduc F, Krzewinski F, Le Fur B, N'Guessan A, Malle P, Kol O, et al. Differentiation of fresh and frozen/thawed fish, European sea bass (Dicentrarchus labrax), gilthead seabream (Sparus aurata), cod (Gadus morhua) and salmon (Salmo salar), using volatile compounds by SPME/ GC/MS. Journal of the Science Food and Agriculture 2012;92(12):25602568.

Mafra I, Ferreira IM, Oliveira MBP. Food authentication by PCR-based methods. European Food Research \& Technology 2008;227(3):649665.

Mahajan MV, Gadekar YP, Dighe VD, Kokane RD, Bannalikar AS. Molecular detection of meat animal species targeting MT 12S rRNA gene. Meat Science 2011;88(1):23-27.

Maiorano G, Knaga S, Witkowski A, Cianciullo D, Bednarczyk M. Cholesterol content and intramuscular collagen properties of pectoralis superficialis muscle of quail from different genetic groups. Poultry Science 2011;90(7):1620-1626.

Mitani T, Akane A, Tokiyasu T, Yoshimura S, Okii Y, Yoshida M. Identification of animal species using the partial sequences in the mitochondrial $16 \mathrm{~S}$ rRNA gene. Legal Medicine 2009;11:S449-S450.
Partis L, Croan D, Guo Z, Clark R, Coldham T, Murby J. Evaluation of a DNA fingerprinting method for determining the species origin of meats. Meat Science 2000;54(4):369-376

Rohman A, Erwanto Y, Man YBC. Analysis of pork adulteration in beef meatball using Fourier transform infrared (FTIR) spectroscopy. Meat Science 2011;88(1):91-95.

Rojas M, González I, García T, Hernández PE, Martín R. Authentication of meat and commercial meat products from common pigeon ( Columba livia) woodpigeon ( Columba palumbus) and stock pigeon (Columba oenas) using a TaqMan ${ }^{\circledR}$ real-time PCR assay. Food Control 2012;23(2):369-376.

Safdar M, Junejo Y. A multiplex-conventional PCR assay for bovine, ovine, caprine and fish species identification in feedstuffs: highly sensitive and specific. Food Control 2015;50(190-194).

Soares S, Amaral JS, Oliveira M, Mafra I. A SYBR Green real-time PCR assay to detect and quantify pork meat in processed poultry meat products. Meat Science 2013;94(1):115-120.

Tamura K, Stecher G, Peterson D, Filipski A, Kumar S. MEGA6: molecular evolutionary genetics analysis version 6.0. Molecular and Biology Evolution 2013;30(12):2725-2729.

Wang Q, Zhang X, Zhang H, Zhang J, Chen G, Zhao D, et al. Identification of 12 animal species meat by T-RFLP on the $12 \mathrm{~S}$ rRNA gene. Meat Science 2010;85(2):265-269.

Zhang J, Huang H, Cai Z, Huang L. Species identification in salted products of red snappers by semi-nested PCR-RFLP based on the mitochondrial 12S rRNA gene sequence. Food Control 2006;17(7):557-56.3 